\title{
Synecological comparisons sustained by ecophysiological fingerprinting of intrinsic photosynthetic capacity of plants as assessed by measurements of light response curves
}

\author{
ULRICH LÜTTGE ${ }^{1,3}$ and FABIO RUBIO SCARANO²
}

(received: September 14, 2006; accepted: September 29, 2007)

\begin{abstract}
Synecological comparisons sustained by ecophysiological fingerprinting of intrinsic photosynthetic capacity of plants as assessed by measurements of light response curves). In some literature variations in photosynthetic rates are considered to be of little relevance for individual fitness. This depends among other things on how one defines fitness, i.e. if one takes strictly Darwinian fitness as seed production or if one needs to evaluate particular traits and consider plant establishment. It also matters if one takes the Darwinian "organism individual" as the central entity in evolution ("individual fitness") or the "species individual" in a modified "Structure of Evolutionary Theory" sensu Stephen Jay Gould. A phenotypically expressed trait like photosynthetic rate, even if intra- and interspecific differences may be small, can matter in habitat performance and niche acquisition. Light dependence curves (LCs) of photosynthetic rates are now readily measured under field conditions using miniaturized equipment of pulse amplitude modulated fluorometers. In contrast to actual momentary measurements of quantum yield of photosynthesis under actually prevailing ambient conditions, LC measurements reflect the expressed intrinsic capacity of photosynthesis. In this review we explore the power of LC measurements yielding cardinal points such as maximum apparent electron transport rate of photosystem II $\left(\mathrm{ETR}_{\max }\right)$ and saturating photosynthetically active radiation $\left(\mathrm{PAR}_{\text {sat }}\right)$ in making intra- and interspecific comparisons of plant performance and synecological fingerprinting in ecophysiological studies across species, sites, habitats and ecosystems.
\end{abstract}

Key words - ecophysiology, fitness, light dependence curves, physiological syn-ecology

RESUMO - (Comparações sinecológicas com base em "fingerprinting" ecofisiológico da capacidade fotossintética intrínseca de plantas avaliada por medições de curvas de resposta à luz). Alguns autores consideram variações em taxas fotossintéticas como pouco relavantes para a aptidão ecológica ("fitness") individual. Isto depende, dentre outras coisas, em como se define aptidão ecológica, i.e. se no senso Darwiniano, como fecundidade, ou se levando em conta caracteres relacionados ao estabelecimento e sobrevivência das plantas. Importa, também, se o "organismo individual" de Darwin é considerado a entidade central na evolução ("individual fitness") ou se a "espécie individual" de Gould. Um caráter expresso fenotipicamente, como taxa fotossintética, ainda que diferenças intra- e interespecíficas possam ser pequenas, pode importar em termos de performance e ocupação de nicho. Curvas de resposta à luz (LCs) de taxas fotossintéticas são prontamente mensuráveis em condições de campo através do emprego de equipamento miniaturizado de fluorômetro de amplitude de pulso modulada. Em contraste com medidas instantâneas de eficiência quântica de fotossíntese, medidas de LC refletem a capacidade fotossintética intrínseca. Nesta revisão nós exploramos o poder de medidas de LC, e seus pontos cardinais derivados tais quais a taxa de transporte de elétrons máxima do fotossistema II $\left(\mathrm{ETR}_{\max }\right)$ e a radiação fotossinteticamente ativa saturante $\left(\mathrm{PAR}_{\text {sat }}\right.$ ), na realização de comparações intra- e interespecíficas para performance das plantas e "fingerprinting" sinecológico em estudos ecofisiológicos entre espécies, localidades, habitats e ecossistemas.

Palavras-chave - aptidão ecológica, curvas de resposta à luz, ecofisiologia, sinecologia fisiológica

\section{Introduction}

"Direct correlations between photosynthetic rates and fitness are rarely observed in natural populations; ..... it is impossible to say that variation in photosynthetic rate, per se, contributed directly to individual fitness". These

1 Darmstadt University of Technology, Institute of Botany, Schittspahnstr. 3-5, D-64289, Darmstadt, Germany

2. Universidade Federal do Rio de Janeiro, CCS, IB, Departamento de Ecologia, Caixa Postal 68020, 21941-970 Rio de Janeiro, RJ

3. Corresponding author: luettge@bio.tu-darmstadt.de statements found in a review by Ackerly et al. (2000) are somewhat perplexing. Certainly "ecophysiological traits ..... are likely to influence fitness and undergo adaptive evolution" (Ackerly et al. 2000), and photosynthesis is among them.

Thus, Niklas (1997) offers a more balanced view of the concept of fitness and about the difficulties in measuring it directly. He argues that the various biological properties contributing to fitness, i.e., an individual's ability to contribute to the gene pool of the next generation relative to that of other individuals, can be grouped into 
two types of categories: those related to survival and those related to reproductive success. Since it would be obviously difficult to measure all pertinent traits in these two categories to achieve some kind of fitness assessment, the usual practise is to select a few traits to measure (often belonging to one of the categories only) and assume that they provide a good assessment of fitness. This is not necessarily a correct assumption. The risks of assuming this correlation between survival and reproductive success are clear from the example given by Niklas (1997): one can easily imagine a long-living sterile plant and/or a fecund ephemeral plant. In this vein, one may also think of $\mathrm{k}$ - and $\mathrm{r}$-strategy species producing small and large number of seeds, respectively (Silvertown 1987).

Considering the basic question how one can define fitness of plants in ecosystems and habitats, is it really as simple as recording sexual reproduction, i.e. flower production and seed number as in Ackerly et al.'s scheme with photosynthetic rate upstream of some physiological "fitness components" with "seed number" as a down stream output of "fitness"? Is it not rather seedling and plant establishment that counts in assessment of fitness? Ecologically, many traits become pertinent: "The individual's fitness (the number of offspring contributed to the next generation*) depends on the success of metabolism and development in capturing and managing available energy and matter. ... all causes of fitness differences, anticipated and unanticipated, are integrated in the measured fitness of genetic variants ..." (Tonsor et al. 2005). Moreover, even within the survival and reproductive success "boxes", there are problems with assumptions. When discussing reproductive success, one will intuitively think of sexual reproduction. But what about clonally propagating individuals showing aggressive interspecific competitiveness and ecophysiological fitness? In the Qira Oasis of the Taklimakan desert (Hotan Province, Chinese Xinjiang Uygur Autonomous Region, China) a clone of Populus euphratica Oliv. of a diameter of $100 \mathrm{~m}$ and a size of at least 4 ha has been identified by molecular fingerprinting using amplified fragment length polymorphism (AFLP) (Bruelheide $e t$ al. 2004). The largest clones known in the world are of Populus tremuloides Michx., i.e. in the Wasatch Mountains in Utah, North America, with 42.9 ha (Grant 1993 ) or even larger elsewhere (81 ha: Kemperman \& Barnes 1976). Would then, to mention as one

\footnotetext{
* i.e., not just the number of seeds produced and perhaps not even only sexually produced offspring, if we may also refer to clonal individuals.
}

ecophysiologically studied example Andira legalis (Geßler et al. 2005a) - which is the most abundant plant in a stretch of "restinga" in coastal Rio de Janeiro state of Brazil - be labelled as fit or unfit? This plant has achieved this high abundance through asexual reproduction and clonal propagation and has not produced a single seedling in the past 10 years (Cirne \& Scarano 2001, Cirne et al. 2003). Here, although even clones may expose genetic variation which is sustained by mutation (Forneck 2004), a further question clearly arising is if it is only genotypic anchorage of traits or also plastic phenotypic expression of physiological traits that counts for performance in ecosystems and habitats and ecological niche acquisition, i.e. in fitness other than just sexual propagation.

The problems related to measuring fitness persist at the population level, when one wants to compare the overall "adaptiveness" of one versus another population of a given species. Seed output, degree of polymorphism, persistence in time, susceptibility to deleterious mutations, ability to increase in size, interspecific competitiveness, and even plant abundance have all been used as measurements of population fitness, and again according to Niklas (1997), despite merits, they all pose theoretical and practical problems. Here, too, an integrated approach combining survival and reproductive parameters is likely to be more successful (e.g. Scarano et al., 2002).

As we fully agree with Niklas's perspective, it is also obvious that ecophysiological traits are still much under-rated in ecological literature, when it comes to assessing fitness [as in Ackerly et al. (2000), see above]. Thus, it is our aim in this paper to discuss the potential of a tool we have been developing to produce an "ecophysiological fingerprint" of intrinsic photosynthetic capacity of plants. It is neither our goal nor our argument that the tool discussed here will finally solve the problem of incorporating the ecophysiological vigour component into fitness estimation. However, we believe that it may elicit a better assessment of the contribution of photosynthesis to fitness.

\section{Feedback networks of genotype, phenotype and environment}

Traits required for generating phenotypes are anchored in the genome, but environmental factors act upon the phenotypes, i.e. the particular traits actually expressed. In the ecology of photosynthesis, genotypically anchored ecophysiological complexes often quoted are $\mathrm{C}_{4}$-photosynthesis and Crassulacean acid metabolism (CAM). Both have evolved polyphyletically many times in the plant kingdom (Lüttge 2004) and many CAM 
plants in particular also show highly pronounced phenotypic plasticity and $\mathrm{C}_{3} / \mathrm{CAM}$ intermediate behaviour in response to environmental cues (Lüttge 2004). Another genetically fixed trait in many species is the sun and shade plant nature, respectively. However, again there is considerable intra-specific plasticity in many species producing both sun and shade types depending on environmental constraints (e.g., Scarano et al. 2002). The genetic basis of all the ecophysiological traits (Ackerly et al. 2000) undisputedly makes population genetics a non escapable approach for understanding both evolutionary aspects of biodiversity and ecosystem functioning (Tomiuk et al. 2004). In addition, for the latter the study of expressed physiological capacities, including photosynthetic capacity, is equally essential as clearly indicated by the network-like interactions of phenotypes, ecotypes and genotypes with phenotypes being the receivers of environmental input and phenotype-genotype feedback (Lüttge 2005). As the most outstanding function of primary producers we therefore remain interested in photosynthetic capacity in relation to ecophysiological fitness.

\section{Photosynthetic light response curves}

Primary reactions of photosynthesis such as quantum use efficiency and apparent electron transport rate (ETR) are now easily measured in the field using miniaturised pulse amplitude modulated fluorometers (see review in Lüttge \& Scarano 2004). One can make instant measurements of potential quantum yield $\left(\mathrm{F}_{\mathrm{v}} / \mathrm{F}_{\mathrm{m}}\right)$ and of effective quantum yield $\left(\Delta \mathrm{F} / \mathrm{F}_{\mathrm{m}}{ }^{\prime}\right)$ of photosystem II of dark and light adapted leaves, respectively (Rascher et al. 2000), in the field. Some instruments, like the MiniPAM of H. Walz (Effeltrich, Germany), provide an internal light curve (LC) programme allowing the rapid measurement of light dependence curves of leaves in the field (Rascher et al. 2000). While the instant measurements of $\Delta \mathrm{F} / \mathrm{F}_{\mathrm{m}}$, reflect momentary activity under actually pertaining ambient conditions, LCs are mostly thought to reflect intrinsically expressed capacity of the plants. Thus, the latter allow intra-specific comparisons of individual plants and interspecific comparisons of different species within habitats and across habitats. A note of caution is that comparative LC measurements should be made at similar times during the day to avoid interference of diurnal variations of expression, which for example were encountered to be very significant at times during a field study of several species of Vellozia in the "Serra do Cipó", Minas Gerais, Brazil (Lüttge et al. 2007). However, the light curve programme of the Mini-PAM allows to generate sets of comparative LCs within a reasonably short time frame, taking about 5 min per LC.

Rascher et al. (2000) have compared the results of instant measurements and LC measurements of $\Delta \mathrm{F} /$ $\mathrm{F}_{\mathrm{m}}{ }^{\prime}$ and ETR of different plants in a montane tropical forest in Ethiopia (figure 1). They show the power of the method for assessing comparative ecophysiological performance. In their comparison instant measurements of $\Delta \mathrm{F} / \mathrm{F}_{\mathrm{m}}{ }^{\prime}$ and $\mathrm{LC}$ measurements showed very close agreement for Peperomia sp. and Kalanchoë densiflora Rolfe and were offset against each other by only a systematic error for Lobelia gibberoa Hemsl. and Solanecio gigas (Vatke) C. Jeffey, and the comparisons revealed interspecific differences between the different species at the site chosen (figure 1). In many other studies in the past we have used the LC approach for characterising plant performance in the field at the autecological level. Light curves allow to deduce cardinal points which are quantitative physiological indicators of intrinsic photosynthetic capacity, such as $\Delta \mathrm{F} / \mathrm{Fm}$ ' and ETR at light saturation, i.e. $\Delta \mathrm{F} / \mathrm{F}_{\mathrm{m}}{ }^{\prime}$-sat and $\mathrm{ETR}_{\max }$, respectively, and saturating photosynthetically active radiation $\left(\mathrm{PAR}_{\mathrm{sat}}\right)$. In more recent studies we have endeavoured at employing such measurements in approaches of physiological synecology (Lüttge \& Scarano 2004) comparing different species and life forms within ecosystems and similar species and life forms across ecosystems (Scarano et al. 2001, 2005 a,b, Duarte et al. 2005, Geßler et al. 2005 a,b). LC cardinal points were used in addition to several other physiological traits in the synecological assessments attempted in these studies.

In the following section we shall use $\mathrm{ETR}_{\max }$ and $\mathrm{PAR}_{\text {sat }}$ in exploring three case studies to illustrate the potential of LC cardinal points in assessments of plant performance at the community level. In the section subsequent to it we then shall address the suggestion that LC cardinal points allow synecological ecophysiological fingerprinting and the evaluation of the roles of generalist and specialist species, respectively, as dominant species in ecosystems.

\section{Three case studies}

Case study 1: Butea monosperma Taub. at different sites in Rajasthan, India - The first example (figure 2, unpublished data of U.L.) shows a comparison of the performance of the legume tree Butea monosperma Taub. in South-Rajasthan, India, at three different sites in the district of Tonk and in two different seasons. Sites 1 and 2 were very dry rocky rupestrian fields at the 


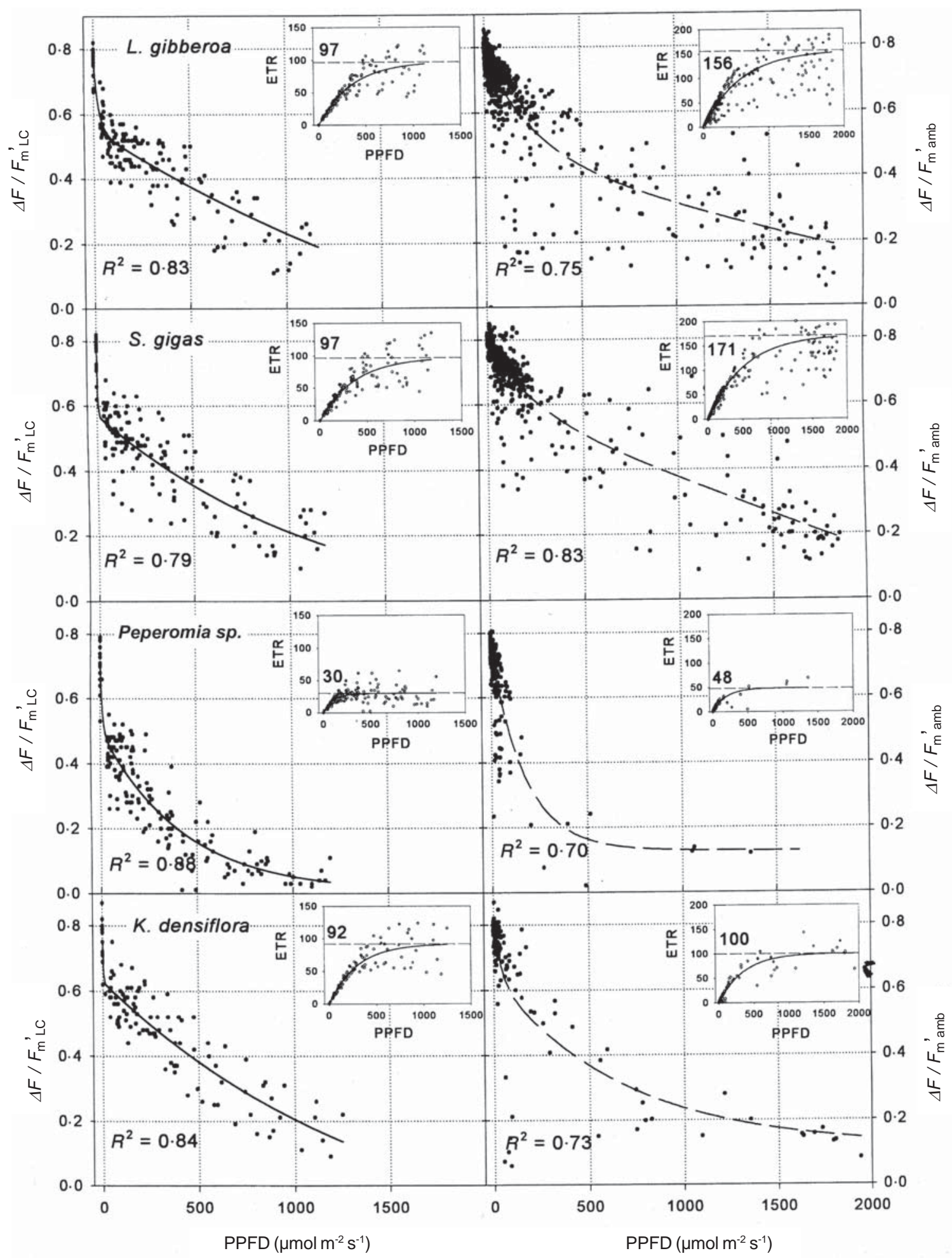

Figure 1. LC-measurements (left panels) and measurements under actual ambient conditions (right panels) of $\Delta \mathrm{F} / \mathrm{F}_{\mathrm{m}}{ }^{\prime}$ (main graphs) and ETR (insets) related to photosynthetic photon flux rate (PPFD = PAR) of from top to bottom Lobelia gibberoa Hemsl., Solanecio gigas (Vatke) C. Jeffey, Peperomia sp. and Kalanchoë densiflora Rolfe in a montane tropical forest in Ethiopia. Individual data points of $\Delta \mathrm{F} / \mathrm{F}_{\mathrm{m}}$ ' were fitted against double exponential functions, which are represented by the lines in the figures $\left(\mathrm{R}^{2}=\right.$ regression coefficients) and data points of ETR were fitted by a single exponential function, where the lines were used to determine ETR $\mathrm{max}_{\max }$ as indicated by the numbers in the inserts $\left(\mu \mathrm{mol} \mathrm{m}{ }^{-2} \mathrm{~s}^{-1}\right)$ [From Rascher et al. 2000, with kind permission of Plant, Cell and Environment]. 
bottom of a small mountain ridge facing East (site 1) and West (site 2), respectively, while site 3 was an irrigated agricultural area. The measurements in October were performed just at the end of the rainy season and those in December 2 to 3 months into the dry season. The intra-specific comparison across sites shows that the exposure does not have strong effects, although there appears to be a trend of better performance of the East-exposed plants at the rocky and hilly site. At the agricultural site the plants showed a somewhat inferior performance at the end of the wet season than the plants in the rupestrian field but they were less affected by season and since the performance of the plants in the rupestrian field declined with progressing dry season the differences became negligible in the dry season.

Case study 2: Mangrove tree-species along a zonation with a sun-exposure gradient on Pohnpei Island, Micronesia - The second example is shown in table 1 where five mangrove tree-species in a sun-exposure zonation show a clear gradient of $\mathrm{ETR}_{\max }$ obtained from light response curves. It illustrates the usefulness of the parameter ETR $_{\max }$ for assessing intrinsic photosynthetic capacity in relation to plant performance in the field.
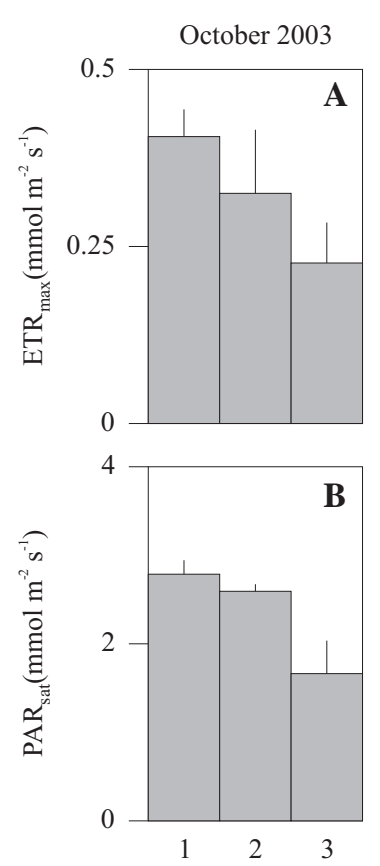
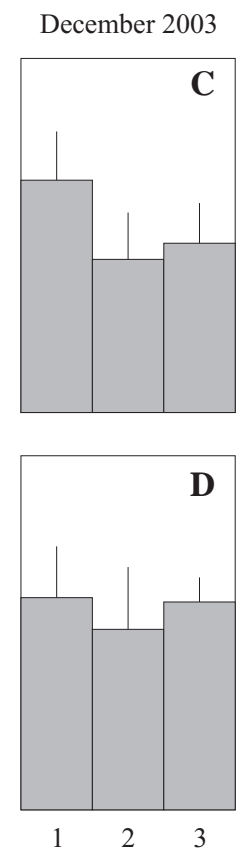

Figure 2. LC-fingerprinting of Butea monosperma at two rocky hilly sites at the foot of a small mountain ridge facing East (site 1) and West (site 2) and in an agricultural plain (site 3) in South-Rajasthan, India, at the end of the rainy season (October 2003) and two to three months into the dry season (December 2003). Error bars are standard deviations.
Table 1. Apparent photosynthetic electron transport rate at an irradiance of $1000 \mu \mathrm{mol} \mathrm{m} \mathrm{m}^{-2} \mathrm{~s}^{-1}$ (i.e. at or very close to saturation) of five mangrove tree-species in a sun-exposure gradient (after data of Kitao et al. 2003)

\begin{tabular}{lc}
\hline Species & $\begin{array}{c}\mathrm{ETR}_{\max } \\
\left(\mu \mathrm{mol} \mathrm{m} \mathrm{s}^{-1}\right)\end{array}$ \\
\hline Sun-exposed pioneer species & \\
$\quad$ Sonneratia alba Sm. & 95 \\
$\quad$ Rhizophora stylosa Griff. & 90 \\
Intermediate species & \\
$\quad$ Bruguiera gymnorrhiza $(\mathrm{L}$.$) Lam.$ & 60 \\
$\quad$ Rhizophora apiculata Blume & 55 \\
Shade-tolerant climax species & \\
$\quad$ Xylocarpus granatum J. König & 40 \\
\hline
\end{tabular}

Case study 3: Exotic tree plantations and regeneration of natural forest in the tropics - The third example is the potential of natural forest regeneration in an exotic tree plantation, which we studied in the ShashemeneMunessa State Forest in the eastern escarpment of the Great Rift Valley in Ethiopia. In many tropical countries, very much also in Brazil (Silva et al. 1995), plantations of exotic trees are occupying vast areas. Such plantations obviously have ecologically adverse effects, such as harmful changes of soil in physical, chemical and biological properties and in competitive strength for water and nutrients, displacement of local flora, native vegetation and fauna, and susceptibility of exotic tree species to epidemic diseases and pests. However, it has also to be considered that they may have advantages, such as information available on propagation techniques, silvicultural behaviour and management practices, their fast growth and wood production and their nurse effects relating to microclimate, protection against erosion and enhancement of litter and humus production (Feyera $e t$ al. 2002). In particular the nurse effect can be very important, as also shown by the present case study. Figure 3 compares ETR $_{\max }$ and PAR $_{\text {sat }}$ for two different adjacent Eucalyptus plantations, E. globulus Labill. and E. saligna $\mathrm{Sm}$., two native species regenerating within the E. saligna plantation (Bersama abyssinica Fresen and Podocarpus falcatus (Thunb.) Endl.) and two native species in a near by remnant natural Podocarpus forest with several hundred year old Podocarpus trees $(P$. falcatus and Croton macrostachys Hochst. Ex. Del.). Thus, from left to right in figure 3 there is kind of a transition from exotic to native trees in a plantation and to native trees in a natural stand. Of course, with the limited number of sites and trees figure 3 is a very rudimentary 


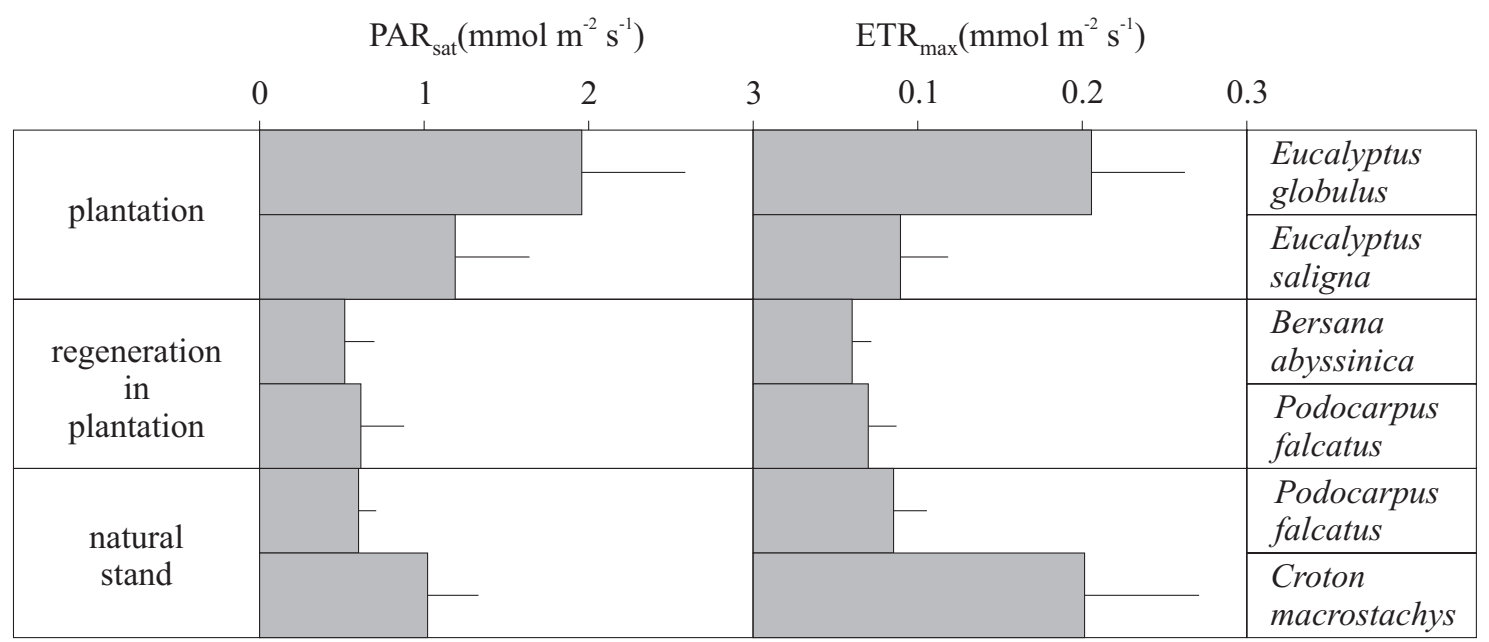

Figure 3. LC-fingerprinting of exotic and native trees in Eucalyptus-plantations and a remnant natural Podocarpus forest in the eastern escarpment of the Great Rift Valley, Ethiopia.

"fingerprint". Nevertheless, it gives structural information at a glance with the sun plant characteristics, i.e. high $\mathrm{ETR}_{\max }$ and $\mathrm{PAR}_{\text {sat }}$, of both the exotic E. globulus in the plantation and $C$. macrostachys in the natural stand, similar behaviour of $P$. falcatus in both the E. saligna plantation and the natural stand, and an almost similar behaviour of P. falcatus and E. saligna in the plantation. Together with additional information, especially a much higher intrinsic water use efficiency of $P$. falcatus, the latter observation led to the conclusion that the valuable native tree $P$. falcatus can well regenerate within the exotic E. saligna-tree plantation, and - appropriate forest management given - even a new Podocarpus-forest may be established (Feyera et al. 2002, Lüttge et al. 2003, Fetene \& Beck 2004).

\section{Synecological ecophysiological fingerprinting using ETR max $_{\text {and PAR }}$ of light curves}

In Brazil we performed a somewhat broader survey of seven generalist and five specialist shrub and tree species in a range of eight ecosystems marginal to the Atlantic Forest which span from rather moist to rather dry. The study was devoted to physiological synecology and, in addition to measurements of light reactions of photosynthesis, several other parameters were assessed, such as carbon and nitrogen levels, soluble carbon and non-protein nitrogen compounds, stable carbon and nitrogen isotope ratios, and the results are laid down in five separate communications (Duarte et al. 2005, Geßler et al. 2005 a,b, Scarano et al. 2005 a,b). The overall result of the study were the following general patterns: (1) at the intra-specific level, ecophysiological performance often - although not always - varied largely in both time and space; (2) at the interspecific level, ecophysiological performance was often - but not always - related to species dominance in the community; and (3) at both intra- and interspecific level, generalists and specialists did not form groups of similarly behaving plants in regard to ecophysiology (Scarano et al. 2005a).

Here we try to extract the ETR ${ }_{\text {max }}$ and PAR ${ }_{\text {sat }}$ data from the LCs to develop a matrix of species and sites or a fingerprint of the synecological situation with respect to photosynthetic capacity. The eight boxes in the horizontal direction (x-axis) in figure 4 are ecosystems from wet to dry, i.e.: (1) a swamp forest; (2) a wet "restinga"; (3) the first dune ridge of an intermediate "restinga"; (4) the second dune ridge of an intermediate "restinga"; (5) a dry "restinga"; (6) a dry dune forest; (7) an inselberg; (8) a semideciduous dry forest.

The 12 vertical boxes (y-axis) in figure 4 correspond to seven generalist species (top) and 5 specialist species (bottom). For simply evaluating the pattern obtained the names of the actual species would not matter. Nevertheless, for clarity they are identified with some comments as follows (from top to bottom in figure 4). Generalists were: (1) Croton compressus Lam., (2) Rheedia brasiliensis (Mart.) Planch \& Triana; (3) Myrsine parvifolia A. DC., a "restinga" generalist; (4) Clusia hilariana Schlecht.; (5) Clusia fluminensis Planch. et Triana, (6) Clusia parvifolia Saldanha et Engl.; (7) Andira legalis Vell. Toledo, a "restinga" generalist. Specialists were: (1) Calophyllum brasiliense Cambess, a wetland specialist; (2) Styllingia dichotoma Muell. Arg., an inselberg specialist; (3) Machaerium obovatum Kuhlm. and Hoehne, a dry forest specialist; (4) Caesalpinia 

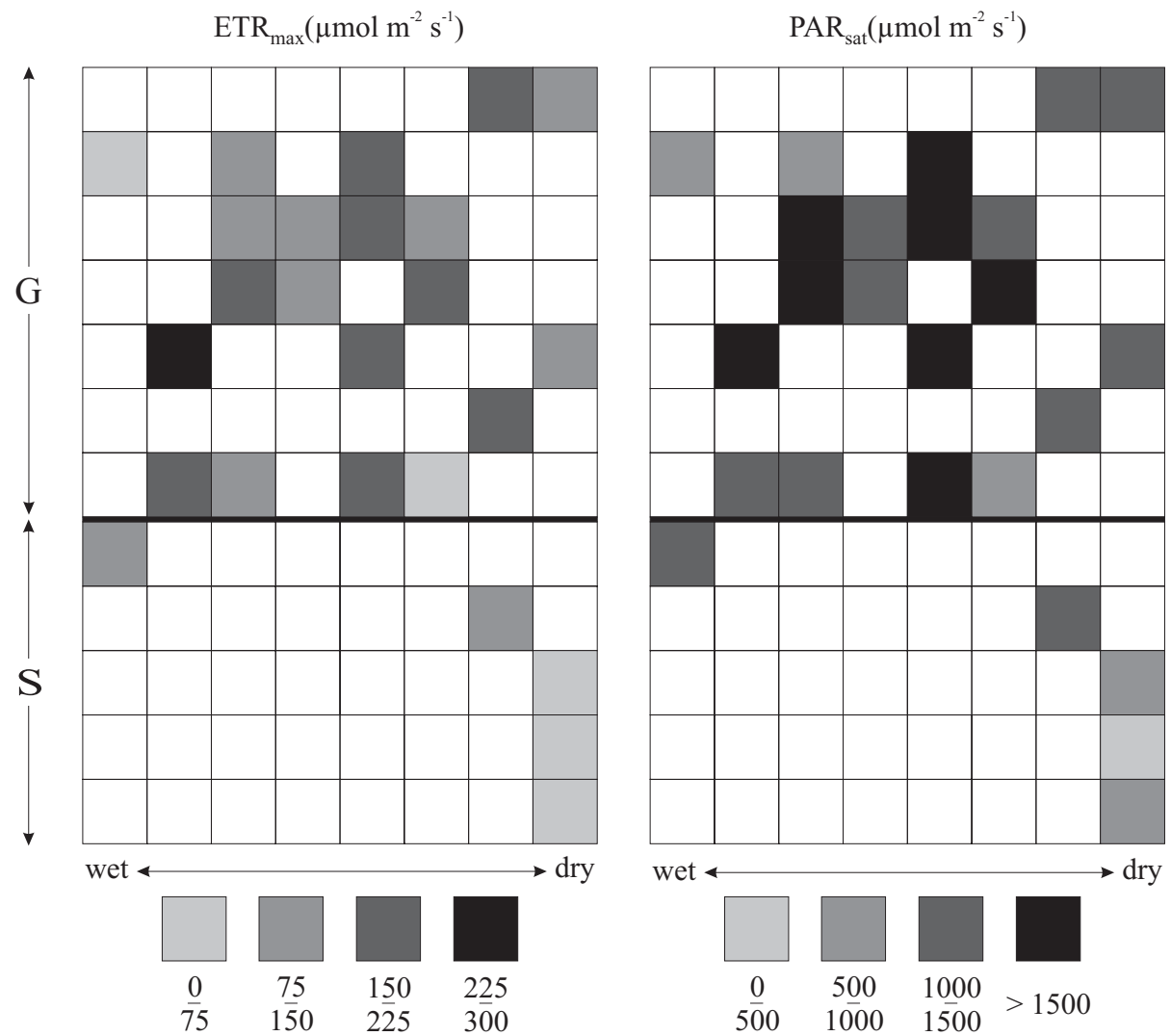

Figure 4. LC-fingerprinting of generalist (G: upper panels) and specialist (S: lower panels) species in a gradient of wet to dry ecosystems and habitats (from left to right) marginal to the Atlantic Forest in Brazil. From light grey to black the boxes indicate four different ranges of ETR max $_{\text {an }}$ and $\mathrm{PAR}_{\text {sat }}$ respectively, as indicated below the panels. White boxes mean that there are not entries. For details of species and sites see text.

echinata Lam., a dry forest specialist; (5) Caesalpinia ferrea Mart. ex. Tul., a dry forest specialist.

A comment is required regarding $C$. brasiliense which is classified correctly as a wetland specialist here but is distributed throughout the South-American continent. Conversely, $C$. hilariana is a habitat generalist but geographically restricted to the States of Rio de Janeiro and Espírito Santo of Brazil. This puts the habitat-type classification made here into a contrast to a possible geographical classification. However, what appears to matter in an attempt of habitat fingerprinting is using generalist and specialist in terms of a broad and narrow habitat-type preference, and thus, this appears to be an appropriate choice. The "fingerprinting" boxes in figure 4 were then obtained by creating four classifications of $\mathrm{ETR}_{\max }$ and $\mathrm{PAR}_{\mathrm{sat}}$ each from the original LC data. Visually in the upper part of the diagram of figure 4 (first four lines for species (1) to (4)) the fingerprints suggest that superior performances were most often found among the generalists in intermediate sites along the wet to dry gradient. This agrees with what one might expect intuitively, i.e. that generalists have an intermediate optimum performance and get weaker in their performance at the extremes.

Hence, they are generalists because their ecological optimum is rather broad. Conversely, species may become generalists via plasticity, and a generalist plant intermediate in phytosociological ranking in a given vegetation may become highly abundant in another one and develop to a dominant species, which may determine ecosystem function. At this point, the dominant form of the generalist can eventually turn into an ecotype which is a genetically stable population (Turesson 1992, Kinzel 1982). Such species must show high performance in rather different types of habitats as suggested by species (5) to (7) in the lower part of the diagram for generalists in figure 4. Thus, if a generalist species is a dominant type may depend here on the site where it occurs, i.e. either being restricted to its given optimum or to plastic occupation of characteristically different habitats via plasticity and eventually the generation of ecotypes. These two different ways may also provide two different explanations of our conclusion (1) above, i.e. that there was large spatiotemporal intra-specific variation in 
performance. Regarding the question of ecotypes, molecular population analysis will be essential (Tomiuk et al. 2004). For a general overview, we think that notwithstanding the still limited number of entries figure 4 already shows the potential of LC based matrices.

The data base for the specialists is much smaller. This is primarily due to the fact that specialists sensu stricto have only entries in one box (one habitat). Moreover, specialists were rarer than generalists in our sample. It may be a challenge though for further work, to try and identify more specialists in a wider array of habitats and to obtain their LC signatures. So far it is seen that the performance of the specialists tends to be poorer than that of the generalists, which is not against intuitive expectation as the specialists studied here are restricted to the extreme habitats where environmental constraints must limit quantitative performance especially in regard to drought. But qualitatively the specialists have a niche and can compete successfully enough to sustain their existence. Thus specialists, e.g. species (3) and (5) of the specialists in figure 4 , are adapted to overcome and in the habitats studied in figure 4, which are largely characterized by a lush vegetation with vigorous interaction - by contrast to patchy plant growth in environmentally extreme habitats - they may not become dominant types. Conversely, specialists can become dominant types in lush vegetation. One then would expect high performance in relation to conclusion (2) above, i.e. that at the interspecific level often ecophysiological performance is related to species dominance, as possibly for species (1) and (2) in the matrix of figure 4.

\section{Conclusion}

Phenotypically expressed intrinsic photosynthetic capacity, including photosynthetic rates, as revealed e.g. by LC cardinal points, remains important in occupation of habitats by plants and in acquisition of ecophysiological niches within habitats. We should not forget that even small differences can matter in niche acquisition and adaptive performance. Phenotypic plasticity itself can be a genotypically anchored trait. This also pertains to intra-specific responses of plants to differently expressed seasonal climatic conditions between different years, and we should not discard this when evaluating photosynthetic rates in relation to fitness. Thus, readily obtained LCs and their cardinal points appear to be very useful quantitative physiological entries in matrices for synecological ecophysiological fingerprinting allowing, for example, to single out dominant plant types as discussed above using the example of ecosystems marginal to the Atlantic Forest in Brazil.

Beyond this, for assessment of species function in ecosystems there is also a strong current trend to apply functional type (FT) classifications (Díaz et al. 2004). This also could benefit from ecophysiological fingerprinting. FTs are non-phylogenetic classifications of plant species, which follows functional or ecosystem traits (Shugart 1997). The term functional type is equivalent to ecological guild or functional group (Wilson 1999). Some of these groups are sometimes promptly detected (e.g., the group of nitrogen fixers in a forest is a functional type), other times they can be a testable hypothesis (e.g., see Scarano 2002), but more often they require detailed data gathering followed by species classifications built up by multivariate analyses. Matrices are species lists on $\mathrm{y}$ and a list of traits on $\mathrm{x}$, for instance. Traits can be either reproductive (sexual system, fecundity, dispersal type, etc), phytosociological (abundance, geographic distribution, habitat preference), ecophysiological (photosynthetic mode, nitrogen fixation, leaf size), etc., and they can be either quantitative or qualitative (Pillar \& Sosinski Junior 2003). Cardinal points derived from LCs can be very useful functional traits to be considered when building up functional classifications. They could be good quantitative traits, perhaps even better than photosynthetic rate, for instance.

If Darwinian fitness in ecosystem and habitat performance is more than actual production of seeds and if it is the "species-individual" which is the essential entity in macroevolution - as it is the "organism-individual" in microevolution - (Gould 2002), LC-matrices may add useful information for developing further insights.

Acknowledgements - We thank M.S. Buckeridge for valuable comments on the manuscript. FRS thanks CNPq for a productivity grant.

\section{References}

ACKERLY, D.D., DUDLEY, S.A., SULTAN, S.E., SCHMITT, J., COLEMAN, J.S., LINDER, C.R., SANDQUIST, D.R., GEBER, M.A., EVANS, A.S., DAWSON, T.E. \& LECHOWICZ, M.J. 2000. The evolution of plant ecophysiological traits: recent advances and future directions. BioScience 50:979-995.

BRUELHEIDE, H., MANEGOLD, M. \& JANDT, U. 2004. The genetical structure of Populus euphratica and Alhagi sparsifolia stands in the Taklimakan desert. In Ecophysiology and habitat requirements of perennial plant species in the Taklimakan desert (M. Runge \& X. Zhang, eds.). Shaker Verlag, Aachen, p.153-160. 
CIRNE, P. \& SCARANO, F.R. 2001. Resprouting and growth dynamics after fire of the clonal shrub Andira legalis (Leguminosae) in a sandy coastal plain in southeastern Brazil. Journal of Ecology 89:351-357.

CIRNE, P., ZALUAR, H.L.T. \& SCARANO, F.R. 2003. Plant diversity, interspecific associations and postfire resprouting on a sandy spit in a Brazilian coastal plain. Ecotropica 9:33-38.

DÍAZ, S., HODGSON, J., THOMPSON, K., CABIDO, M., CORNELISSEN, J.H.C., JALILI, A., MONTSERRATMARTÍN, G., GRIME, J.P., ZARRINKAMAR, F., ASRI, Y., BAND, S.R., BASCONCELO, S., CASTRO-DÍEZ, P., FUNES, G., HAMZEHEE, B., KHOSHNEVI, M., PÉREZHARGUINDEGUY, N., PÉREZ-RONTOMÉ, M.C., SHIRVANY, F.A., VENDRAMINI, F., YAZDANI, S., ABBAS-AZIMI, R., BOGAARD, A., BOUSTANI, S., CHARLES, M., DEHGHAN, M., DE TORRES-ESPUNY, L., FALCZUK, V., GUERRERO-CAMPO, J., HYND, A., JONES, G., KOWSARY, E., KAZEMI-SAEED, F., MAESTRO-MARTÍNEZ, M., ROMO-DÍEZ, A., SHAW, S., SIAVASH, B., VILLAR-SALVADOR, P. \& ZAK, M.R. 2004. The plant traits that drive ecosystems: Evidence from three continents. Journal of Vegetation Science 15:295-304.

DUARTE, H.M., GEßLER, A., SCARANO, F.R., FRANCO, A.C., DE MATTOS, E.A., NAHM, M., RENNENBERG, H., ZALUAR, H.L.T. \& LÜTTGE, U. 2005. Ecophysiology of six selected shrub species in different plant communities at the periphery of the Atlantic Forest of SE-Brazil. Flora 200:456-476.

FETENE, M. \& BECK, E. 2004. Water relations of indigenous versus exotic tree species, growing at the same site in a tropical montane forest in southern Ethiopia. Trees Structure and Function 18:428-435.

FEYERA, S., BECK, E. \& LÜTTGE, U. 2002. Exotic trees as nurse-trees for the regeneration of natural tropical forests. Trees Structure and Function 16:245-249.

FORNECK, A. 2004. Plant breeding: clonality - a concept for stability and variability during vegetative propagation. Progress in Botany 66:164-183.

GEßLER, A., DUARTE, H.M., FRANCO, A.C., LÜTTGE, U., DE MATTOS, E.A., NAHM, M., SCARANO, F.R., ZALUAR, H.L.T. \& RENNENBERG, H. 2005a. Ecophysiology of selected tree species in different plant communities at the periphery of the Atlantic Forest of SE-Brazil. II. Spatial and ontogenetic dynamics in deciduous Andira legalis. Trees Structure and Function 19:510-522.

GEßLER, A., DUARTE, H.M., FRANCO, A.C., LÜTTGE, U., DE MATTOS, E.A., NAHM, M., RODRIGUES, P.J.F.P., SCARANO,F.R. \& RENNENBERG,H. 2005b. Ecophysiology of selected tree species in different plant communities at the periphery of the Atlantic Forest of SE-Brazil III. Three legume trees in a semideciduous dry forest. Trees Structure and Function 19:523-530.
GOULD, S. J. 2002. The structure of evolutionary theory. Belknap Press Harvard University, Cambridge, Massachusetts.

GRANT, M.C. 1993. The trembling giant. Discover (Los Angeles) 84:82-89.

KEMPERMAN,J.A.\&BARNES, B.V. 1976. Clone size in American aspens. Canadian Journal of Botany 54:2603-2607.

KINZEL, H. 1982. Pflanzenökologie und Mineralstoffwechsel. Verlag Eugen Ulmer, Stuttgart.

KITAO, M., UTSUGI, H., KURAMOTO, S., TABUCHI, R., FUJIMOTO, K., LIHPAI, S. 2003. Light-dependent photosynthetic characteristics indicated by fluorescence in five mangrove species native to Pohnpei Island, Micronesia. Physiologia Plantarum 117:376-382.

LÜTTGE, U. 2004. Ecophysiology of crassulacean acid metabolism (CAM). Annals of Botany 93:629-652.

LÜTTGE, U. 2005. Genotypes - phenotypes - ecotypes: Relations to crassulacean acid metabolism. Nova Acta Leopoldina NF 92, 342:177-193.

LÜTTGE, U. \& SCARANO, F.R. 2004. Ecophysiology. Revista Brasileira de Botânica 27:1-10.

LÜTTGE, U., BERG, A., FETENE, M., NAUKE, P., PETER, D. \& BECK, E. 2003. Comparative characterization of photosynthetic performance and water relations of native trees and exotic plantation trees in an Ethiopian forest. Trees Structure and Function 17:40-50.

LÜTTGE, U., DUARTE, H.M., SCARANO, F.R., MATTOS, E.A. de, CAVALIN, P.O., FRANCO, A.C., FERNANDES, G.W. 2007. Physiological ecology of photosynthesis of five species of Velloziaceae in the rupestrian fields of Serra do Cipó, Minas Gerais, Brazil. Flora (in press).

NIKLAS, K.J. 1997. The Evolutionary Biology of Plants. The University of Chicago Press, Chicago.

PILLAR, V.D. \& SOSINSKI JUNIOR, E.E. 2003. An improved method for searching plant functional types by numerical analysis. Journal of Vegetation Science 14:323-332.

RASCHER, U., LIEBIG, M. \& LÜTTGE, U. 2000. Evaluation of instant light-response curves of chlorophyll fluorescence parameters obtained with a portable chlorophyll fluorometer on site in the field. Plant, Cell and Environment 23:1397-1405.

SCARANO,F.R., DUARTE, H.M., RIBEIRO K.T., RODRIGUES, P.J.F.P., BARCELLOS, E.M.B., FRANCO, A.C., BRULFERT, J., DELÉENS, E. \& LÜTTGE, U. 2001. Four sites with contrasting environmental stress in southeastern Brazil: relations of species, life form diversity, and geographical distribution to ecophysiological parameters. Botanical Journal of the Linnean Society 136:345-364.

SCARANO, F.R., DUARTE, H.M., RÔÇAS, G., BARRETO, S.M.B., AMADO, E.F., REINERT, F., WENDT, T., MANTOVANI, A., LIMA, H.R.P. \& BARROS, C.F. 2002. Acclimation or stress symptom? An integrated study of intraspecific variation in the clonal plant Aechmea bromeliifolia, a widespread CAM tank-bromeliad. Botanical Journal of the Linnean Society 140:391-401. 
SCARANO, F.R., DUARTE, H.M., FRANCO, A.C., GEßLER, A., DE MATTOS, E.A., RENNENBERG, H. \& LÜTTGE, U. 2005a. Physiological synecology of tree species in relation to geographic distribution and ecophysiological parameters at the Atlantic forest periphery in Brazil: an overview. Trees Structure and Function 19:493-496.

SCARANO, F.R., DUARTE H.M., FRANCO, A.C., GEßLER, A., DE MATTOS, E.A., NAHM, M., RENNENBERG, H., ZALUAR, H.L.T. \& LÜTTGE, U. 2005b. Ecophysiology of selected tree species in different plant communities at the periphery of the Atlantic Forest of SE-Brazil. I. Behaviour of three different species of Clusia in an array of plant communities. Trees Structure and Function 19: 497-509.

SHUGART, H.H. 1997. Plant and ecosystem functional types. In Plant functional types: their relevance to ecosystem properties and global change (T.M. Smith, H.H. Shugart \& F.I. Woodward, eds.). Cambridge University Press, Cambridge, p.20-43.
SILVA JÚNIOR, M.C., SCARANO, F.R. \& CARDEL, F.S. 1995. Regeneration of an Atlantic forest formation in the understory of a Eucalyptus grandis plantation in southeastern Brazil. Journal of Tropical Ecology 11:147-152.

SILVERTOWN, J. 1987. Introduction to Plant Population Ecology. $2^{\text {nd }}$ ed. Longman, London.

TOMIUK, J., ROEDENBECK, I.A. \& KÖHLER, W. 2004. Population genetics: biodiversity in anthropogenic landscapes - population genetics and ecological modelling. Progress in Botany 66:112-143.

TONSOR, S.J., ALONSO-BLANCO, C. \& KOORNNEEF, M. 2005. Gene function beyond the single trait: natural variation, gene effects and evolutionary ecology in Arabidopsis thaliana. Plant, Cell and Environment 28: 2-20.

TURESSON, G. The genotypic response of the plant species to the habitat. Hereditas 3:211-350.

WILSON, J.B. 1999. Guilds, functional types and ecological groups. Oikos 86:507-522. 